\title{
INTERACTION BETWEEN RESISTANCE TO Septoria tritici AND PHENOLOGICAL STAGES IN WHEAT
}

\author{
Jorge Omar Giecoㅜㄹ Jorge Dubcovsky²; Luis Eduardo Aranha Camargo ${ }^{3 *}$ \\ ${ }^{1}$ USP/ESALQ - Programa de Pós-Graduação em Genética e Melhoramento de plantas, C.P. 83 - 13400-970 - \\ Piracicaba, SP - Brasil. \\ ${ }_{3}^{2}$ Department of Agronomy \& Range Science, University of California, Davis, CA 95616 - USA. \\ ${ }^{3}$ USP/ESALQ - Depto. de Entomologia, Fitopatologia e Zoologia Agrícola, C.P. 9 - 13418-900 - Piracicaba, SP - \\ Brasil. \\ *Corresponding Author <leacamar@esalq.usp.br>
}

\begin{abstract}
Studies dedicated to understanding the behavior of pathogens in relation to their hosts are the starting point for any breeding program aimed to develop resistant cultivars. The objective of this study was to analyze the resistance to Septoria tritici Rob in $77 \mathrm{~F}_{11}$ progenies of wheat derived from the three-way cross Tadinia $\times($ Yecora rojo $\times$ UC554) in the phenological stages of seedling, tillering, and flag leaf/flowering. Three field experiments were conducted where plants were artificially inoculated at one of the above mentioned phenological stages by spraying with a suspension of conidia. A randomized block design with four replications was used in each experiment. Disease evaluations were made by measuring the foliar area covered with chlorotic and necrotic lesions in the seedling and tillering stages and the leaf area covered with pycnidia in the flag leaf/flowering stage, using disease rating scales. Differences $(P \leq 0.0001)$ were detected among progenies for Damaged Leaf Area (DLA) in all phenological stages. Joint analysis of variance for DLA indicated interaction between progeny and phenological stage $(P \leq 0.0001)$ for all binary combinations analyzed (seedling-tillering, seedling-flag leaf and tillering-flag leaf) as it also did for the triple combination involving the three phenological stages. It is necessary to evaluate resistance in more than one phenological stage to guarantee the correct selection of resistant genotypes.
\end{abstract}

Key words: Mycosphaerella graminicola, Triticum aestivum, leaf blotch, disease resistance

\section{INTERAÇÃO ENTRE RESISTÊNCIA A Septoria tritici E ESTÁDIOS FENOLÓGICOS EM TRIGO}

\begin{abstract}
RESUMO: Estudos destinados a entender o comportamento de patógenos em relação a seus hospedeiros são o ponto de partida para qualquer programa de melhoramento cujo objetivo é obter cultivares resistentes. $\mathrm{O}$ objetivo do presente trabalho foi analisar a resistência a Septoria tritici Rob em 77 progênies $\mathrm{F}_{11}$ de trigo derivadas do cruzamento Tadinia $\times($ Yecora rojo $\times$ UC554) nos estádios fenológicos de plântula, perfilhamento e folha bandeira. Para tal, foram conduzidos três experimentos de campo, onde as plantas foram inoculadas em um dos estádios fenológicos acima mencionados através da pulverização com uma suspensão de conídios, em um delineamento em blocos casualizados, com quatro repetições, onde as parcelas experimentais foram constituídas por uma fileira de um metro de comprimento contendo oito plantas, com um espaçamento de 0,17 m entre linhas e 0,13 m entre plantas. As avaliações da severidade da doença foram feitas registrando-se a área foliar coberta por lesões necróticas e cloróticas, nos estádios de plântula e perfilhamento e área foliar coberta por picnídios no estádio de folha bandeira-floração com auxílio de escalas de notas. Foram detectadas diferenças $(P \leq 0,0001)$ entre progênies para área foliar lesionada (AFL) nos estádios fenológicos estudados. Análises de variância conjuntas para AFL indicaram uma interação entre progênies e estádios fenológicos $(P \leq 0,0001)$ para todas as combinações binárias analisadas (plântula-perfilhamento, plântula-folha bandeira e perfilhamento-folha bandeira) assim como para a combinação tripla envolvendo os três estádios fenológicos. É necessário avaliar resistência em mais de um estádio fenológico para garantir a correta seleção de genótipos resistentes.

Palavras-chave: Mycosphaerella graminicola, Triticum aestivum, mancha foliar, resistência a doenças
\end{abstract}

\section{INTRODUCTION}

Amongst the main factors limiting greater yields in wheat are the rusts and Septorioses of leaves, glumes, and nodes. Leaf blotch, caused by Septoria tritici Rob., is one of the main diseases of wheat in more than fifty countries, especially in the USA, Canada, Egypt, Argentina, Uruguay, Brazil, and various countries in Europe (Eyal et al., 1985). This fungus is essentially a leaf pathogen and rarely causes blotches on glumes. In the initial stages of the disease the blotches are clear yellow, small, globular or oblong, sometimes narrower than the spots 
caused by Septoria nodorum. In the more advanced stages of infection, the blotches become linear and almost parallel to the veins and can cover all of the leaf and sheath.

Leaves heavily infected are straw colored and present numerous dispersed, black and prominent pycnidia, conferring a speckled aspect to the leaf. The disease is thus also known as "speckled leaf blotch" (Gair et al., 1987; Wiese, 1977). The substitution of locally adapted varieties by exotic, high yielding cultivars, with low stature and precocious ripening, resulted in the increase in the incidence of leaf blotch in the last 20 years (King et al., 1983). Generally, the last two traits show a positive correlation with susceptibility to leaf blotch (Eyal, 1981; Ziv et al., 1981). Moreover, modifications in cultural practices, such as direct planting, use of nitrogenous fertilizers, and irrigation, have all contributed to an increase in the severity of the disease (Eyal et al., 1987).

Resistance to Septoria tritici is generally expressed through the reduction of the foliar area covered with pycnidia and/or necrosis. There is an apparent discrepancy between the number and mode of action of the genes that govern resistance to Septoria tritici in wheat. Narvaez \& Caldwell (1957), Rillo \& Caldwell (1966), Wilson (1979), Lee \& Gough (1984), Somasco et al. (1996), found resistance of a qualitative type, controlled by one to three major genes. Rosielle \& Brown (1979) indicated the existence of three recessive genes controlling resistance in the cultivar 'Seabreeze'. Jlibene et al., (1994) and Simon \& Cordo (1998), however, indicated the presence of a quantitative, or polygenic, resistance in spring wheat, emphasizing that the additive gene effects were more important than the non-additive. Eyal (1981) also described the presence of polygenic resistance with additive, dominant and partially dominant effects, as well as recessive genes and modifiers.

Given the economic relevance, the development of strategies to control the disease are of great importance. Amongst the strategies available to combat diseases, genetic resistance stands out as the most appropriate in terms of stability, economy, and environmental impact. The starting point for any work aiming to obtain resistant materials is the correct evaluation of the genotypes. Not only it is important to select an adequate inoculation method for each disease, but also to choose the correct phenological stage in which the inoculation should be made. However, studies relating the degree of resistance to Septoria tritici Rob. as a function of phenological stage are scarce. Therefore, the objective of the present study was to analyze the expression of resistance to Septoria tritici Rob in $\mathrm{F}_{11}$ progenies of wheat derived from the cross of Tadinia $\times$ (Yecora rojo $\times$ UC554) in the phenological stages of seedling, tillering and flag leaf/flowering.

\section{MATERIAL AND METHODS}

\section{Plant material}

A segregant population composed of $77 \mathrm{~F}_{11}$ families derived from the triple cross Tadinia $\times$ (Yecora rojo $\times$ UC554) was used. These families were developed using the bulk method where the advancement of the generations involved successive self-pollinations in the absence of deliberate selection. Tadinia is considered resistant, whereas Yecora rojo is susceptible and UC 554 moderately resistant.

\section{Disease resistance trials}

Three field experiments were conducted in

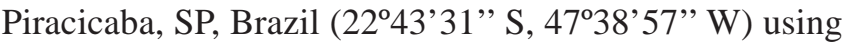
a randomized blocks design with four replications. Plants were inoculated once at one of the phenological stage considerated. Experimental units consisted of one meter rows, $0.17 \mathrm{~cm}$ apart, containing eight plants. Each block consisted of 77 progenies plus the three parental lines. The susceptible control "Cooperación Calquin” was used as a spreader row around each block. For the seedling and tillering resistance trials, the progenies were seeded in July, 2000, and inoculated 15 and 25 days after planting, respectively, while for the flag leaf trial, they were seeded in June, 2000, and inoculated 70 days after planting. Plants were inoculated by spraying with a suspension of conidia calibrated to $10^{6}-10^{8}$ spores $\mathrm{mL}^{-1}$ according to Dhingra \& Sinclair (1986). The isolate used in the inoculations (IPBr1) was obtained from wheat leaves naturally infected by the fungus. Following inoculation, a humid chamber was made by covering the blocks with a plastic film, and maintained for $36 \mathrm{~h}$. Thirty days after inoculation, disease was evaluated by estimating the damaged leaf area (DLA). For seedling and tillering stages DLA was assessed as percentage of leaf area covered with chlorotic and necrotic lesions, whereas for the flag leaf stage, DLA was assessed as percentage of the leaf area covered with pycnidia. In both cases, a rating scale was used, where 0 represents absence of symptoms and 5 indicates 87 to $100 \%$ of damaged leaf area (Eyal \& Brown, 1976; Ziv \& Eyal, 1978).

\section{Statistical analyses}

Individual and joint analyses of variance were performed. The purpose of the joint analysis was to identify interactions between resistance of genotypes (progenies) $\times$ phenological stages. Pairwise regression analyses between disease severities of $F_{11}$ progenies inoculated in different phenological stages were also made. Data analyses were performed using the statistical program SAS for Windows, version 8.0 (1999). Regression graphs of severity of the $F_{11}$ progenies were prepared with the help of statistical software STATISTICA for Windows version 5.0 (2002). 


\section{RESULTS AND DISCUSSION}

The individual analysis of variance for DLA indicated differences $(P \leq 0.0001)$ among progenies in all phenological stages. Homogeneity of variance was observed for the mean squares of the residues for each phenological stage which allowed the joint analysis of variance (data not shown). The interaction progeny $\times$ phenological stage was significant $(P \leq 0.0001)$ for all tested binary combinations (seedling $\times$ tillering, seedling $\times$ flag leaf, and tillering $\times$ flag leaf) as well as for the triple combination (seedling $\times$ tillering $\times$ flag leaf) (Table 1 ). Pairwise regression analyses between mean DLA of $\mathrm{F}_{11}$ progenies inoculated in different stages also indicated a general poor relationship between variables (Figure 1). The best relationship was that between resistance at the seedling and tillering stages $\left(\mathrm{R}^{2}=0.34 ; P \leq 0.0001\right)$, followed by seedling $\times$ flag leaf $\left(\mathrm{R}^{2}=0.19 ; P \leq 0.0001\right)$ and tillering $\times$ flag leaf $\left(\mathrm{R}^{2}=0.10 ; P \leq 0.0108\right)$.

Significant interactions in the particular case of combinations involving the flag leaf stage were determined in large part by a group of progenies that manifested susceptibility when inoculated in the seedling, but resistance when inoculated in the tillering and flag leaf stages, showing no pycnidia or minimal pycnidial coverage (non-sporulating lesions). Progenies which behaved in the opposite way were also noticed (Figure 2). This suggest the presence of stage-specific resistance genes as has been described in other wheat pathosystems. Kolmer (1997), for instance, described different genes controlling resistance to Puccinia recondita f.sp. tritici in seedling despite that some genes that acted in the adult plant were also involved in seedling resistance in some cultivars. Similar results were obtained by Torabi \& Nazari (1998), analyzing Iranian wheat cultivars in the presence of Puccinia striiformis f.sp. tritici.

The presence of non-sporulating lesions in adult plants is a known phenotype of partial resistance and has

Table 1 - Joint analysis of variance for DLA in parents and $\mathrm{F}_{11}$ wheat progenies [Tadinia $\times$ (Yecora rojo $\mathrm{x} \mathrm{UC}$ 554)] at the phenological stages of seedling, tillering, and flag leaf.

\begin{tabular}{lrccrc}
\hline VS & DF & SS & MS & F & Pr $>$ F \\
\hline Stage & 2 & 13.03185 & 6.515925 & 0.97 & $0.3822^{\text {ns }}$ \\
Block (stage) & 9 & 7.118672 & 0.790964 & 17.49 & $0.0001^{* *}$ \\
Progenies & 79 & 1412.137 & 17.87516 & 2.99 & $0.0001^{* *}$ \\
Stage $\times$ Prog. & 158 & 945.9459 & 5.987000 & 132.36 & $0.0001^{* *}$ \\
Residual & 711 & 32.15972 & 0.045232 & & \\
Total & 959 & 2410.393 & & & \\
\hline
\end{tabular}

$\mathrm{CV}=8.47 ; \mathrm{R}^{2}=0.98$; General mean $(\mathrm{DLA})=2.51$

References: VS: Variation sources; DF: Degrees of freedom; SS: sum of Squares; MS: Mean squares. ${ }^{\text {ns: }}$ no significant, *: significant at $P=0.05$, **: significant at $P=0.01$. been reported in the pathosystem wheat $\mathrm{x}$ Septoria tritici (Simon \& Cordo, 1998; Zuckerman et al., 1996) and also in other pathosystems involving wheat such as wheat $x$ Erysiphe graminis f. sp. tritici (Pearce et al., 1996), Xanthomonas campestris pv. cerealis (Attari et al., 1996), Stagonospora nodorum (Du et al., 1999) and Puccinia recondita (Singh et al., 2001). Selection of genotypes possessing this type of resistance is highly desirable, because it alleviates the selective pressure on the pathogen, which could lead to appearance of new physiological races.

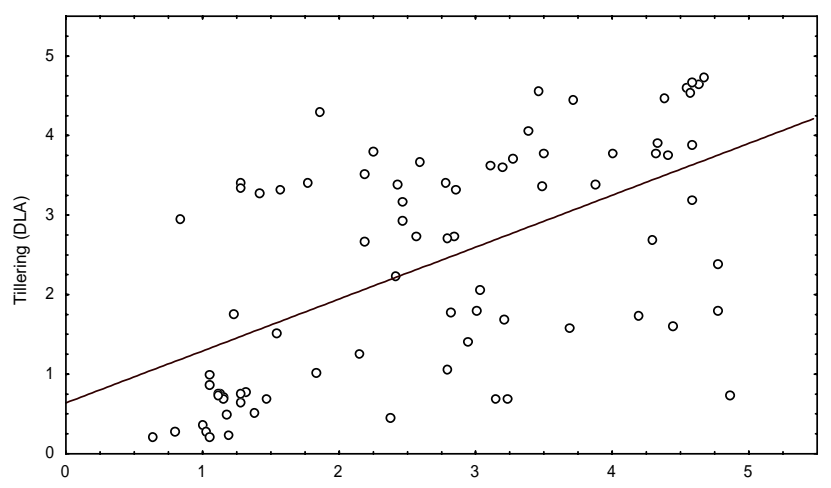

A Seedling (DLA)

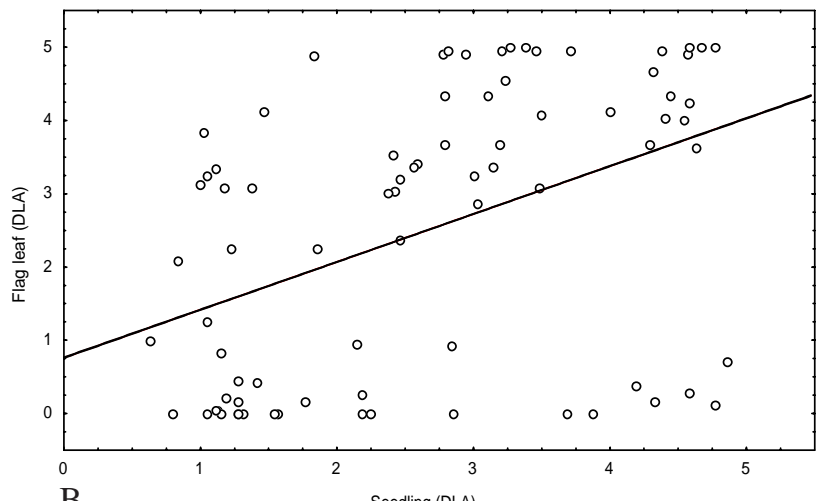

B Seedling (DLA)

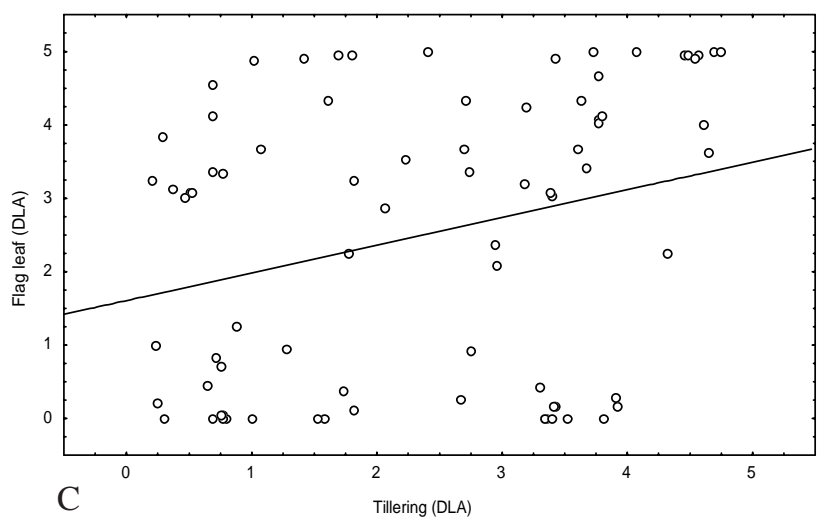

Figure 1 - Regression plots of mean damaged leaf area of $F_{11}$ wheat progenies when inoculated with Septoria tritici at the phenological stages of seedling and tillering (A), seedling and flag leaf (B) and tillering and flag leaf (C). DLA = damaged leaf area. 
The behavior of the parental lines Tadinia, Yecora rojo and UC554 in the phenological stages of seedling, tillering and flag leaf is shown in Table 2. No significant variation was observed in resistance or susceptibility degrees as a function of phenological stages. The absence of significant interaction in the parental lines, but its presence among $F_{11}$ progenies, can be the result of epistasis caused by certain combinations of parental alleles in some of the progenies.

Results herein reported agree with those reported by Kema \& Van Silfhout (1997), who did not found any relationship between resistance at the seedling and adult plant stages when 22 wheat cultivars were inoculated with 14 isolates of Septoria tritici. However, they differ in part from those of Somasco et al., (1996), who described a positive correlation between resistance at the stages of seedling and adult plant in $\mathrm{F}_{3}$ progenies derived from the crosses Tadinia $\times$ Yecora rojo, and Tadinia $\times$ Inia 66R.

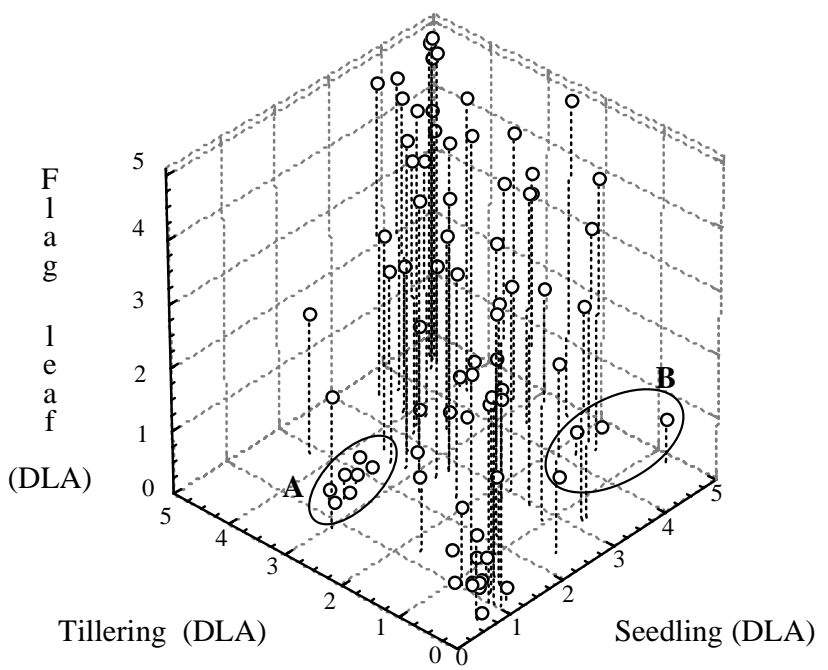

Figure 2 - Mean damaged leaf area (DLA) of $\mathrm{F}_{11}$ wheat progenies inoculated with Septoria tritici at the phenological stages of tillering, seedling and flag leaf. Ellipses highlight progenies resistant when inoculated at the seedling and flag leaf but susceptible at the tillering stage (A) or progenies susceptible at the seedling but resistant at the tillering and flag leaf stages (B).

Table 2 - Damaged leaf area (DLA) of parental lines of $F_{11}$ progenies assessed when plants were inoculated at three phenological stages .

\begin{tabular}{lccc}
\hline & \multicolumn{3}{c}{ Phenological stages } \\
\cline { 2 - 4 } & Seedling & Tillering & Flag leaf \\
\hline Cultivar & DLA & DLA & DLA \\
\hline Tadinia & 0.89 & 0.86 & 1.00 \\
Yecora rojo & 4.44 & 4.61 & 4.92 \\
UC 554 & 2.00 & 2.14 & 2.50 \\
\hline
\end{tabular}

DLA: Eyal \& Brown scale: $(0-5)(0=0 \%, 1=12 \%, 2=25 \%, 3=50 \%$, $4=75 \%, 5=87 \%$ ).
This difference could be explained by the use of UC 554, a moderately resistant line, as one of the progenitors of the segregating population, and indicates that interactions between resistance to Septoria tritici in wheat and phenological stages depends on the genotypes involved. It becomes thus clear that in the presence of a strong interaction between genotype $\times$ phenological stage, selection of plants based on the evaluation of disease resistance only at one stage could result in the loss of many progenies that in other stages could possess favorable resistance genes. Under these circumstances, it is recommended the application of low or intermediate levels of selection intensity, and that disease resistance evaluations be carried out in at least two different phenological stages.

These conclusions are limited to the isolate used in the inoculations. Because Septoria tritici present high genetic variability, future works should be guided to verify the differential behavior in the resistance manifested by the tested genotypes in the different phenological states using different pathogen isolates.

\section{ACKNOWLEDGEMENTS}

This research was supported by Fundação de Amparo a Pesquisa do Estado de São Paulo -Brazil, and the research at the US by USDA-IFAFS competitive grant 2001-04462.

\section{REFERENCES}

ATTARI, H.E.; SARRAFI, A.; GARRIGUES, S.; DECHAMPGUILLAUME, G.; BARRAULT, G. Diallel analysis of partial resistance to an Iranian strain of bacterial leaf streak (Xanthomonas campestris pv. cerealis) in wheat. Plant Pathology, v.45, p.1134-1138, 1996.

DHINGRA, O.D.; SINCLAIR, J.B. Basic plant pathology methods. 3.ed. Boca Raton: CRC Press, 1986. p. 119-178: Establishment of disease and testing for resistance.

DU, C.G.; NELSON, L.R.; McDANIEL, M.E. Septoria and Stagonospora diseases of cereals: A compilation of global research. In: INTERNATIONAL SEPTORIA WORKSHOP, México, DF, 1999. Proceedings. México: CIMMYT, 1999. p.160-162.

EYAL, Z. Integrated control of Septoria diseases of wheat. Plant Disease, v.65, p.763-768, 1981.

EYAL, Z.; BROWN, M.B. A quantitative method for estimating density of Septoria tritici pycnidia on wheat leaves. Phytopathology, v.66, p.1114, 1976.

EYAL, Z.; SCHAREN, A.L.; PRESCOTT, J.M.; van GINKEL, M. Enfermedades del trigo causadas por Septoria: Conceptos y métodos relacionados con el manejo de estas enfermedades. México, D.F.: CIMMYT, 1987. 45p.

EYAL, Z.; SCHAREN, A.L.; HUFFMAN, M.D.; PRESCOTT, J.M. Global insights into virulence frequencies of Mycosphaerella graminicola. Phytopathology, v.75, p.1456-1462, 1985.

GAIR, R.; JENKINS, J.E.E.; LESTER, E. Cereal pests and diseases. 4.ed. Suffolk: Farming Press, 1987. 268p.

JLIBENE, M.; GUSTAFSON, J.P.; RAJARAM, S. Inheritance of resistance to Mycosphaerella graminicola in hexaploid wheat. Plant Breeding, v.112, p.301-310, 1994.

KEMA, G.H.J.; van SILFHOUT, C.H. Genetic variation for virulence and resistance in the wheat-Mycosphaerella graminicola pathosystem III. Comparative seedling and adult plant experiments. Phytopathology, v.87, p.266-272, 1997 
KING, J.E.; COOK, R.J.; MELVILLE, S.C. A review of Septoria diseases of wheat and barley. Annals of Applied Biology, v.103, p.345-373, 1983.

KOLMER, J.A. Virulence in Puccinia recondita f. sp. tritici isolates from Canada to genes for adult-plant resistance to wheat leaf rust. Plant Disease, v.81, p.267-271, 1997.

LEE, T.S.; GOUGH, F.J. Inheritance of Septoria leaf blotch (S. tritici) and Pyrenophora tan spot ( $P$. tritici repentis) resistance in Triticum aestivum cv. Carifen 12. Plant Disease. v.68, p.848-851, 1984.

NARVAEZ, I.; CALDWELL, R.M. Inheritance of resistance to leaf blotch of wheat caused by Septoria tritici. Phytopathology, v.47, p.529-530, 1954.

PEARCE, W.L.; van SANFORD D.A.; HERSHMAN, D.E. Partial resistance to powdery mildew in soft red winter wheat. Plant Disease, v.80, p.13591362, 1996

RILLO, A.O.; CALDWELL, R.M. Inheritance of resistance to Septoria tritici in Triticum aestivum subsp. vulgare 'Bulgaria 88'. Phytopathology, v.56, p.897, 1966. /Abstract/

ROSIELLE, A.A.; BROWN, A.G.P. Inheritance, heritability and breeding behavior of three sources of resistance to Septoria tritici in wheat. Euphytica, v.28, p.385-392, 1979.

SAS INSTITUTE. SAS/STAT User's Guide, Release 8.0 edition. Cary: SAS Institute, 1999.

SIMON, M.R.; CORDO, C.A. Diallel analysis of four resistance components to Septoria tritici in six crosses of wheat (Triticum aestivum). Plant Breeding, v.117, p.123-126, 1998.

SINGH, D., PARK, R.F.; Mc INTOSH, R.A. Inheritance of seedling and adult plant resistance to leaf rust of selected Australian spring and English winter wheat varieties. Plant Breeding, v.120, p.503-507, 2001.
SOMASCO, O.A.; QUALSET, C.O.; GILCHRIST, D.G. Single-gene resistance to Septoria tritici blotch in the spring wheat cultivar 'Tadinia'. Plant Breeding, v.115, p.261-267, 1996.

STATISTICA. Statistical Software 5.0 version. 1997. Tulsa, OK: Stat Soft, Inc. (2002) Electronic Statistics Textbook. http//www. Statsoft.com/ textbook/stathome.html/ (10/04/2002).

TORABI, M.; NAZARI, K. Seedling and adult plant resistance to yellow rust in Iranian bread wheat. Euphytica, v.100, p.51-54, 1998.

WIESE, M.V. Septoria Leaf and Glume Blotch. Compendium of wheat diseases. St. Paul: Americam Phytopathological Society, 1977. 106p.

WILSON, R.E. Resistance to Septoria tritici in two wheat cultivars determined by independent, single dominant genes. Australian Plant Pathology, v.8, p.16-18, 1979.

ZIV, O.; EYAL, Z. Assessment of yield component losses caused in plants of spring wheat cultivars by selected isolates of Septoria tritici. Phytopathology, v. 68, p. 791-796, 1978.

ZIV, O.; SACKS, J.M.; EYAL, Z. Inheritance of tolerance to Septoria leaf blotch of wheat. Phytopathology, v.71, p.119-123, 1981.

ZUCKERMAN, E.; ESHEL, A.; EYAL, Z. Physiological aspects related to tolerance of spring wheat cultivars to Septoria tritici Blotch. Phytopathology, v.87, p.60-65, 1996.

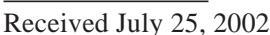

Accepted April 15, 2004 